\title{
Ergonomic Risks in the Printing Company and Workers' Wellbeing
}

\author{
Gundega Stradina ${ }^{1}$, Janis Ievins ${ }^{2},{ }^{1-2}$ Riga Technical University, Latvia \\ Zenija Roja ${ }^{3}$, Valdis Kalkis ${ }^{4}$, Henrijs Kalkis ${ }^{5},{ }^{3-5}$ University of Latvia
}

\begin{abstract}
The aim of the study was to analyze the ergonomic risks in the printing company and to study the impact of ergonomics risks on employees' wellbeing. The study involved 67 company workers aged 18 to 67 years. In the study, physical load evaluation methods and questionnaire on welfare and psychoemotional risks at work, adopted by Swedish Environmental Research Institute, were used. It was proved that production workers were subjected to increased physical workload. At work they are exposed to physical pressure on hands, shoulders and back. The workload is more affected by the increase in work tension due to limited time of order execution. It was concluded that ergonomic risks partly affect employees' wellbeing; however, uncertainty about the organization's long-term plans and lack of understanding of employees' contribution to performance of the organization are the most important reasons that affect the employees' wellbeing.
\end{abstract}

Keywords: Ergonomic risks, load, printing, tension, welfare.

\section{INTRODUCTION}

Recently manufacturing industry, including the printing industry, has grown rapidly in Latvia. Paper manufacturing and printing account for approximately $4 \%$ of total manufacturing turnover and employment [1] and the demand for Latvian printing products in the external market is growing. Introduction of modern technologies in the printing industry has contributed to changes in work environment risks. Nowadays Latvian companies, as elsewhere in the world, are dominated by the following risks: ergonomic (forced postures, repetitive work operations, lifting and moving of heavy weight, work in front of a computer), psychosocial (time limit / overtime, low pay, work related conflicts, etc.), as well as organizational (shift work, lack of short breaks, lack of knowledge of the organization's plans for the future, lack of understanding of the importance of their work contribution) [2], [3], [4]. Studies in Europe and the U.S. show that organization's economic performance is closely related to people's skills and behavior. Unhealthy, unsafe and discomforting environment limits human's physical and mental abilities and, as a result, has a negative impact on workers' behavior and organizational performance as a whole. Therefore, many world-leading companies that are aware of importance of these issues are investing in employees' welfare in order to promote the company's growth. For example, vice president of IBM Martin J. Sepulveda says: “IBM Company's absolute priority is moving towards workers' health, safety and welfare. It is a commitment to enhance every employee's quality of life [5].

Many different processes characterize production of printing products for the modern enterprise: printing of materials, post-processing of finished products - cutting, stitching, packing, finished product storage and handling and so on. It may be concluded that printing workers are exposed to diverse risks of combined exposures. At the same time, it should be noted that in recent years in Latvia this sector has experienced growth for diseases caused by ergonomic and organizational risks at work [6]. Employees are suffering from work-related muscular, skeletal and connective tissue (WRMS) diseases, as well as of the peripheral nervous system (PNS) diseases, which are caused by work in awkward postures, repetitive work operations, prolonged work hours, conflicts at work, time restrictions, shifts, etc. This is supported by studies of other countries, which have emphasized that printing workers, involved in overload, have a big risk of WRMSD and psychiatric diseases [7], [8]. WRMSD and psychiatric diseases are a serious problem in the organization as they increase disability, raise insurance costs, as well as the amount of money spent on training and staff and, of course, reduce the company's operational efficiency and quality. Hence, there is a need for ergonomic intervention to reduce the production process errors as well as inability to work and accidents, thereby improving productivity and quality of work. Scientists have proven that ergonomic improvements justify the costs [9]. Good ergonomics is good economics [10], [11]. Therefore, the aim of this study was to analyze the ergonomic risks in the printing company and to study their impact on employees' wellbeing. The study selected one of the leading printing companies in Latvia engaged in the provision of services related to the production of printing products.

\section{METHODS}

1) Checklist for ergonomics risks at work by Kalkis V. and Roja Z., 2005. The questionnaire was used to identify those categories of workers, who are most exposed to heavy physical work during working hours, and parts of the body that are mostly under pressure while working, as well as organizational flaws [13].

2) Key Item Method (KIM) for determining the physical load of the work: considers the ergonomic conditions of weight lifting and the repetitive hand moves [13], [14].

3) Quick Exposure Check (QEC) method: designed for ergonomic risk identification and load determination on different parts of the body in order to assess the impact of load on the musculoskeletal system [15].

4) Workability index calculations by Ilmarinen J., Tuomi K. 2004 [16]. Workability is defined as employees' existing capacity and forecast for the near future. It helps the employer timely detect the flaws in work organization that are often associated with human factors, such as reduction of staff resources, age, degree of task difficulty, temporal load and diseases of the workers. 
5) Checklist for wellbeing at work by Antonsson A.B., Alverez E. [17]. With the help of this questionnaire, personnel's welfare or wellbeing, as well as performance of the organization can be determined.

\section{RESULTS AND DISCUSSION}

Production department employees $(n=67)$ aged 18 to 67 participated in the survey of existing ergonomic risk (see Fig. 1).

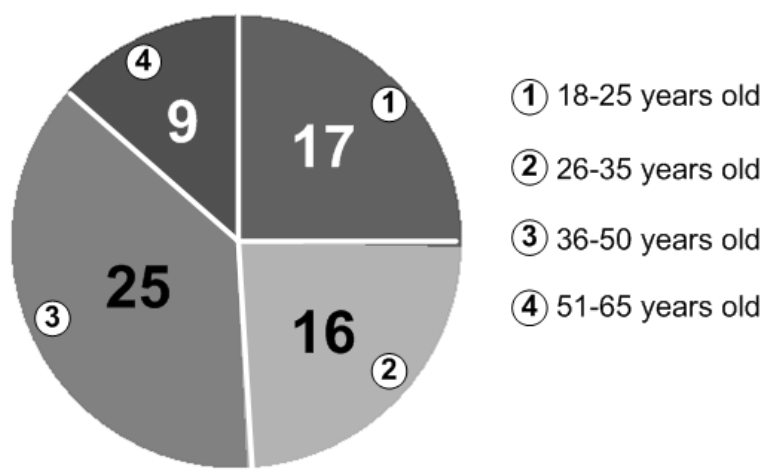

Fig. 1. The survey of workers exposed to breakdown by age.

The diagram shows that the production department employees are of different age. A majority of employees comprise the age group of 36 to 50 years. The age groups of 18-25 years and 26-35 years are mostly comprised by employees that work at the company for no more than 3 years, while for the age group of 36-50 the average length of service is 9 years. Staff considers that the predominant figure of the load is monotonous work (prolonged repetitive work tasks).

More congested parts of the body, according to the employees' subjective views, are wrists and fingers, back, shoulders and lower back. Average weight of the finished product packages is $2.5 \mathrm{~kg}$. The staff believes that the stacking of finished product packages on pallets is provided with good ergonomic conditions: a wide work area and a maximum pallet height of 1.20 meters. This, of course, makes the job easier, as there is no need to raise hands above shoulder height while forming a pallet; however, bending deeply contributes to fatigue.
$40 \%$ of respondents complained about insufficient time for rest during breaks to overcome fatigue. Employees do not do relaxation exercises during the rest breaks for muscle relaxation. Employees are not satisfied with the workload planning, since they are often required to work overtime.

Evaluation of physical activity by KIM-A method (Lifting, Carrying, and Pulling) shows that the workers under consideration are exposed to II and III levels of occupational risk (see Table 1).

The results show that only for 2 occupations - the first and third category offset pressmen - a physical activity is increased, as it has been assessed as the II degree of risk. For other occupations the risk level was determined as the III degree accordingly, which means that a physical activity is substantially increased. It should be noted that physical load of the stapling machine operator assistants, post-processed printing products operators and warehouse workers is very close to the IV level of risk (high physical load). The obtained results suggest that long-term work in the above-mentioned conditions is related to overload, which promotes the development of work-related musculoskeletal diseases and mental health problems [9], [12].

Assessment of manual physical workload risk of the employees using KIM-B method (frequent manual handling operations) indicates that: 1 st and 3rd categories of offset pressmen and warehouse workers are exposed to the load of II degree on the hands, but post-processed printing products operators are exposed to the IV degree of risk (high level of physical load). However, manual physical workload of the offset printer assistants, stapling equipment operators, helpers, and finished production trimming equipment operators is valued as the III degree of risk (significantly increased). The results show an urgent need for ergonomic intervention (see Table 2).

The obtained results indicate overload of certain parts of the body (shoulders, upper back and wrist), which could be explained by the frequent movements of hands during repetitive work operations and working in the upright position.

TABLE I

Physical ACTIVITy RATING IN THE PRINTING COMPANY

\begin{tabular}{|c|c|c|c|c|c|c|}
\hline \multirow[t]{2}{*}{ Occupation } & \multicolumn{5}{|c|}{ Key indicators (rating points*) } & \multirow[t]{2}{*}{ Risk level } \\
\hline & $\mathrm{M}$ & $\mathrm{P}$ & $\mathrm{C}$ & I & RS & \\
\hline 1st category offset pressman & 1 & 2 & 1 & 4 & 16 & II \\
\hline 3rd category offset pressman & 1 & 2 & 1 & 4 & 16 & II \\
\hline Offset pressman's assistant & 1 & 4 & 1 & 6 & 36 & III \\
\hline Stitching machine operator & 1 & 4 & 1 & 6 & 36 & III \\
\hline Stitching machine operator's assistant & 1 & 4 & 1 & 8 & 48 & III \\
\hline Finished products cutting unit operator & 1 & 4 & 1 & 6 & 36 & III \\
\hline Printing products finishing operator & 1 & 4 & 1 & 8 & 48 & III \\
\hline Warehouse worker & 1 & 4 & 1 & 8 & 48 & III \\
\hline
\end{tabular}


TABLE II

EVALUATION OF EMPLOYEES' HAND AND PHySICAL WORKLOAD RISK LEVEL

\begin{tabular}{|c|c|c|c|c|c|c|c|c|}
\hline \multirow[t]{2}{*}{ Occupation } & \multicolumn{7}{|c|}{ Key indicators (rating points*) } & \multirow{2}{*}{$\begin{array}{l}\text { Risk } \\
\text { level }\end{array}$} \\
\hline & $\mathrm{F}$ & $\mathrm{O}$ & $\mathrm{C}$ & $\mathrm{P}$ & $\mathrm{M}$ & I & RS & \\
\hline 1st category offset pressman & 1 & 1 & 0.5 & 1 & 1 & 3 & 13.5 & II \\
\hline 3rd category offset pressman & 1 & 1 & 0.5 & 1 & 1 & 3 & 13.5 & II \\
\hline Offset pressman's assistant & 1 & 1 & 0.5 & 2 & 1 & 6 & 33 & III \\
\hline Stitching machine operator & 1 & 1 & 0.5 & 2 & 1 & 6 & 33 & III \\
\hline Stitching machine operator's assistant & 1 & 1 & 0.5 & 2 & 1 & 6 & 33 & III \\
\hline Finished products cutting unit operator & 1 & 1 & 0.5 & 2 & 1 & 6 & 33 & III \\
\hline Printing products finishing operator & 2 & 1 & 0.5 & 3 & 2 & 6 & 51 & IV \\
\hline Warehouse worker & 1 & 1 & 0.5 & 1 & 1 & 4 & 18 & II \\
\hline
\end{tabular}

Despite the previous evaluation results, employees' workability is either very good or good, as indicated by the calculated workability index (see Fig. 2).

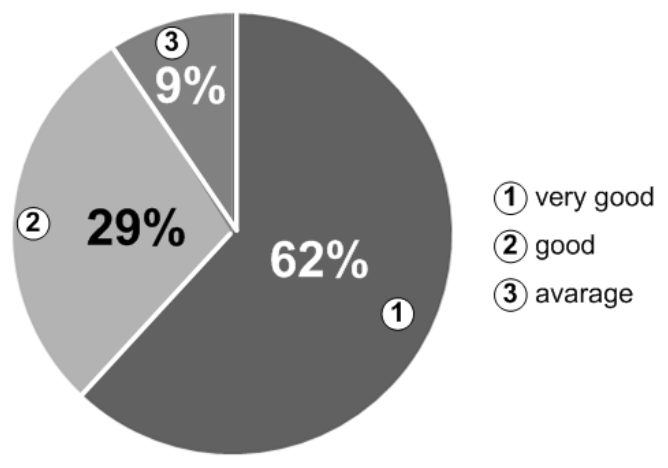

Fig. 2. Employees' workability.

It should be noted that workability of $62 \%$ of the employees is very good, of $29 \%$ - good and only of $9 \%-$ average. Analyzing the subjective assessment of existing working capacity in comparison with the best one, it is concluded that there are no significant changes in the total workability characteristics of the company. Employees objectively evaluate their ability to work: $57 \%$ of those employed are very good, $30 \%$ - good, $7 \%$ - average and 6\% excellent.

Survey results on wellbeing at work show that the wellbeing of office workers is evaluated basically as good or acceptable, but the production department employees consider that there is a need for improvements in the management and, in particular, it is necessary to define clearly business objectives, to discuss company's plans with subordinates more often, to notify contribution of each individual to the organization's performance (see Fig. 3).

This could be explained by shortcomings in the organization and partly by the low education level of workers. Such assessment requires the employers to focus more on their employees and to provide the necessary information related to

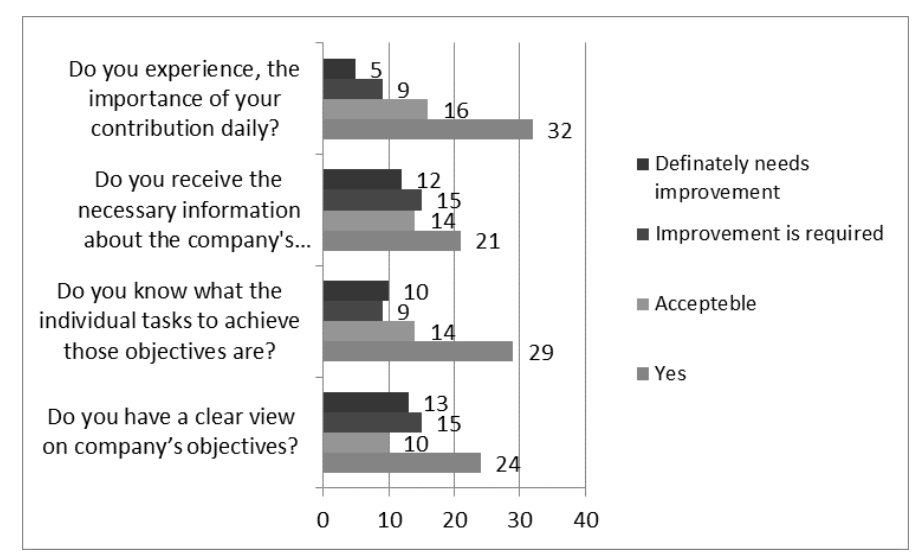

Fig. 3. Employees' evaluation of the company's goals and information.

the development of the organization. Employees noted that the workload is not evenly distributed. For example, at the end of the year orders increase; as a result, workload increases dramatically, and employees are forced to work overtime. A positive fact is that the employment relationships are highly valued. Therefore, no improvements are required.

\section{CONCLUSIONS}

It is concluded that ergonomic risks only partly affect employee's wellbeing, but more problematic issues are the lack of knowledge of the organization's long-term plans for them and the lack of understanding of their work contribution to the organization's performance. The recommendations are focused on organizational issues of the overall social and technical system, paying special attention to humans - the key element of the system.

\section{REFERENCES}

[1] Economic Development of Latvia Report [online]. Riga, June 2012 [accessed 10 November 2013]. Available: http://www.em.gov.lv

[2] V. Kalkis, Z. Roja, Work environment risk factors and workers' health protection. Riga: Elpa-2, 2001. 500 pp. (in Latvian) ISBN 9984-543-69-2.

[3] M.F. Polanyi, D.C. Cole, D.E. et al. Beaton, Upper limb work-related musculoskeletal disorders among newspaper employees: cross-sectional survey results. American Journal of Industrial Medicine. 1997, vol. 32, pp. 620-628.

http://dx.doi.org/10.1002/(SICI)1097-0274(199712)32:6<620::AIDAJIM8>3.0.CO;2-T 
[4] B.S. Bernard, S. Fine, M. Petersen, T. Hales, Job task and psychosocial risk factors for work-related musculoskeletal disorders among newspaper employees. Scand. J. Work Environ. Health. 1994, vol. 20, pp. 417-426. http://dx.doi.org/10.5271/sjweh.1379

[5] Wellfare of Emploees in IBM [online]. March 2013 [accessed 20 October 2013]. Available: http://www.eurofound.europa.eu/

[6] State Labour Inspectorate Annual Report 2012. [online]. [accessed 10 November 2013]. Available: http://www.vdi.gov.lv/

[7] D.E. Beaton, D.C. Cole, M. et al. Manno, Describing the burden of upperextremity musculoskeletal disorders in newspaper workers: what difference do case definitions make? Journal of Occupational Rehabilitation. 2000, vol. 10, no. 1, pp. 39-53. http://dx.doi.org/10.1023/A:1009489712094

[8] J.C. Rosecrance, T.M. Cook, C.L. Zimmermann, Active surveillance for the control of cumulative trauma disorders: a working model in the newspaper industry. J. Orthop Sports Phys. Ther. 1994, vol. 19, no. 5, pp. 267-276.

http://dx.doi.org/10.2519/jospt.1994.19.5.267

[9] M.J. Smith, P. Carayon, Work organization and ergonomics. Applied Ergonomics. 2000, vol. 31, pp. 649-662. http://dx.doi.org/10.1016/S0003-6870(00)00040-5

Gundega Stradina, Human Resource Manager and Occupational Health and Safety Specialist at Reneprint, Ltd. In 2013 she was awarded a Master's Degree in Work Safety by Riga Technical University. She specializes in the field of labor protection and personal management.

Organization: Reneprint, Ltd.

Tel: +37167607174

E-mail: gundega.stradina@gmail.com

Address: Maskavas Str. 291/1-110, Riga, LV-1063, Latvia

Janis Ievins, Professor and also the Head of the Institute of Labour Safety and Civil Defence at Riga Technical University, the Faculty of Engineering Economics and Management. In 1993 he was awarded a Degree of Doctor of Economics (Dr.oec.) by Riga Technical University. He delivers lectures on work safety, management and economics. He specializes in work safety and economic aspects of labor protection, as well as risk assessment. He is an Ambassador of the European Network Education and Training in Occupational Safety and Health (ENETOSH).

Organization: Riga Technical University

Tel: +37129272394

E-mail: Janis.Ievins@ @rtu.lv

Address: Kalnciema Str.6, Riga, LV-1048, Latvia

Zenija Roja, Associate Professor at the Faculty of Chemistry of the University of Latvia. In 2002 she was awarded a Master's Degree of Ergonomics and in 2005 - a Degree of Doctor of Medical Sciences (Dr.med.) by Riga Stradins University. She is a certified European Ergonomist (Eur.Erg.). She delivers lectures on ergonomics, occupational health and workplace health promotion. She specializes in the area of occupational health and load ergonomics. She is an Expert of the Latvian Council of Science in the field of public health. She is a President of the Latvian Ergonomics Society, and Council Member of International Ergonomics Association and Federation of European Ergonomics Societies.

Organization: University of Latvia

Tel: +37129563591

E-mail: zenija.roja@lu.lv

Address: K. Valdemara Str. 48, Riga, LV-1013, Latvia
[10] H.W. Hendrick, Good Ergonomics is Good Economics [online]. Proceedings of the Human Factors and Ergonomics Society 40th Annual Meeting, Human Factors and Ergonomics Society, Santa Monica,1996 [accessed 10 November 2013]. Available: https://www.hfes.org//Web/

[11] H.W. Hendrick, B. Kleiner, Macroergonomics: An introduction to work system design. Santa Monica CA: Human Factors and Ergonomics Society, 2001

[12] Z. Roja, Ergonomcis basics. Riga: Drukatava. 2008. 190 pp. (in Latvian) ISBN 978-9984-798-79-0.

[13] V. Kalkis, Work environment risk assessment methods. Riga: Latvian Education Found, 2008. 242 pp. (in Latvian) ISBN 9984-9558-6-9.

[14] U. Steinberg, G. Caffier, Methodische Aspekte bei der Anwendung der Lastenhandhabungsverordnung. Z. Arbwiss. 1998, vol. 2, no 24, p.101109.

[15] G. David, V. Woods, P. Buckle, Further development of the usability and validity of the Quick Exposure Check. University of Surrey, Guildford, HSE Books, 2005.

[16] J. Ilmarinen, K. Tuomi, Past, present and future of work ability. People and Work Research Reports, Finnish Institute of Occupational Health, Helsinki. 2004, vol. 65, p. 1-25.

[17] A.B. Antonsson, E. Alverez, Checklist for Well-being at Work and the Atmosphere at Work [online]. IVL Svenska Miljöinstitutet AB [accessed 10 November 2013] Available: http://www.prevent.se

Valdis Kalkis, Professor at the Faculty of Chemistry of the University of Latvia. In 1973 he was awarded a Ph.D. (candidate of Chemical Sciences) by Russian State Supreme Certificate Commission, in 1992 he was awarded a Degree of Doctor of Chemistry (Dr.chem.), and in 1998 - a Degree of Habilitate Doctor of Chemistry (Dr.habil.chem.) by the University of Latvia. $\mathrm{He}$ is a Director of professional labor protection master study program "Working Environment Safety and Expertise" and delivers lectures in work expertise, polymer chemistry, radioecology and household chemistry. He specializes in working environment risk assessment, ergonomics and radiation chemistry. He is an Expert of the Latvian Council of Science in the field of physical chemistry and nuclear chemistry. He is a Board Member of the Latvian Ergonomics Society and certified European Ergonomist (Eur.Erg.).

Organization: University of Latvia

Tel: +37129198476

E-mail: valdis.kalkis@lu.lv

Address: K. Valdemara Str. 48, Riga, LV-1013, Latvia

Henrijs Kalkis, Assistant Professorat the University of Latvia, Faculty of Economics and Management. In 2013 he was awarded a Degree of Doctor of Business Management Sciences (Dr.sc.admin) by the University of Latvia. He delivers lectures on quality management methods, business management, and ergonomics management. He specializes in occupational health and work safety, ergonomics, as well as risk assessment. He is a Board Member of the Latvian Ergonomics Society. $\mathrm{He}$ is a certified European Ergonomist (Eur.Erg.). He is also an Expert of the Latvian Council of Science in the field of management science.

Organization: University of Latvia

Tel: +37167034749

E-mail: henrijs.kalkis@lu.lv

Address: Aspazijas Blvd. 5, Riga, LV-1010, Latvia 